\title{
Regulators of G-protein signaling 4 in adrenal gland: localization, regulation, and role in aldosterone secretion
}

\author{
Damian G Romero ${ }^{1,2}$, Ming Yi Zhou ${ }^{3}$, Licy L Yanes ${ }^{4}$, Maria W Plonczynski ${ }^{1}$, Tanganika R Washington ${ }^{1,2}$, \\ Celso E Gomez-Sanchez ${ }^{1,2}$ and Elise P Gomez-Sanchez ${ }^{1,2,5}$ \\ ${ }^{1}$ Division of Endocrinology, G V (Sonny) Montgomery VA Medical Center and ${ }^{2}$ Department of Medicine, The University of Mississippi Medical Center, 2500 \\ North State Street, Jackson, Mississippi 39216, USA \\ ${ }^{3}$ DNA Core, University of Missouri-Columbia, Columbia, Missouri 65211, USA \\ ${ }^{4}$ Departments of Physiology and Biophysics and ${ }^{5}$ Pharmacology and Toxicology, The University of Mississippi Medical Center, Jackson, Mississippi 39216, USA \\ (Requests for offprints should be addressed to D G Romero; Email: dromero@medicine.umsmed.edu)
}

\begin{abstract}
Regulators of G-protein signaling (RGS proteins) interact with $\mathrm{G} \alpha$ subunits of heterotrimeric $\mathrm{G}$-proteins, accelerating the rate of GTP hydrolysis and finalizing the intracellular signaling triggered by the G-protein-coupled receptor (GPCR)-ligand interaction. Angiotensin II (Ang II) interacts with its GPCR in adrenal zona glomerulosa cells and triggers a cascade of intracellular signals that regulates steroidogenesis and proliferation. On screening for adrenal zona glomerulosa-specific genes, we found that RGS4 was exclusively localized in the zona glomerulosa of the rat adrenal cortex. We studied RGS4 expression and regulation in the rat adrenal gland, including the signaling pathways involved, as well as the role of RGS4 in steroidogenesis in human adrenocortical H295R cells. We reported that RGS4 mRNA expression in the rat adrenal gland was restricted to the adrenal zonal glomerulosa and upregulated
\end{abstract}

by low-salt diet and Ang II infusion in rat adrenal glands in vivo. In H295R cells, Ang II caused a rapid and transient increase in RGS4 mRNA levels mediated by the calcium/calmodulin/ calmodulin-dependent protein kinase and protein kinase $\mathrm{C}$ pathways. RGS4 overexpression by retroviral infection in H295R cells decreased Ang II-stimulated aldosterone secretion. In reporter assays, RGS4 decreased Ang II-mediated aldosterone synthase upregulation. In summary, RGS4 is an adrenal gland zona glomerulosa-specific gene that is upregulated by aldosterone secretagogues, in vivo and in vitro, and functions as a negative feedback of Ang II-triggered intracellular signaling. Alterations in RGS4 expression levels or functions may be involved in deregulations of Ang II signaling and abnormal aldosterone secretion.

Journal of Endocrinology (2007) 194, 429-440

\section{Introduction}

Regulators of G-protein signaling (RGS proteins) comprise a complex and diverse family of proteins that interact with the activated $G \alpha$ subunits of heterotrimeric G-proteins accelerating GTP hydrolysis and consequently $\mathrm{G} \alpha$ inactivation and termination of G-protein signaling (Berman \& Gilman 1998, De Vries \& Gist Farquhar 1999, Burchett 2000, Ross \& Wilkie 2000, De Vries et al. 2000, Hollinger \& Hepler 2002, Abramow-Newerly et al. 2006, Sato et al. 2006). G-protein signaling pathways are essential for adrenal gland regulation. Peptide hormones angiotensin II (Ang II), adrenocorticotrophic hormone (ACTH), and endothelin-1, potent physiological inducers of adrenal steroidogenesis, regulate adrenal cells through G-proteinmediated intracellular signaling pathways. G-proteins are heterotrimeric proteins composed of $G \alpha, G \beta$, and $G \gamma$ polypeptides. When the ligand binds its seven-transmembrane G-protein-coupled receptor (GPCR), it causes a conformational change of the receptor that promotes the exchange of GDP with GTP on the G $\alpha$ subunit of G-proteins. When G-protein binds GTP, it becomes activated and the $G \alpha$ subunit dissociates from the $G \beta \gamma$ complex. Both the activated $G \alpha$ and the $G \beta \gamma$ complex interact with effector molecules to generate the intracellular signaling events triggered by the ligand. Termination of signaling depends on the rate of hydrolysis of the GTP bound to the $G \alpha$ protein. G $\alpha$ has intrinsic GTPase activity, but its hydrolysis rate is too slow to account for the rapid termination of the intracellular signaling observed in physiological processes. RGS-mediated acceleration of the $G \alpha$-protein intrinsic GTPase activity overcomes this rate-limiting step in GPCR inactivation and signaling termination.

More than 20 members of the RGS family of polypeptides are characterized by the presence of a highly conserved $\sim 130$ amino acid RGS domain to which the $G \alpha$ subunit of heterotrimeric G-proteins is bound. RGS4 is a member of the 
$\mathrm{B} / 4 \mathrm{R}$ subfamily within the $\mathrm{RGS}$ protein family that is characterized by the presence of an amphipathic helix domain in addition to the RGS domain common to all family members (Berman \& Gilman 1998, De Vries \& Gist Farquhar 1999, Burchett 2000, Ross \& Wilkie 2000, De Vries et al. 2000, Hollinger \& Hepler 2002, Blumer 2005, Abramow-Newerly et al. 2006, Sato et al. 2006). RGS4 interacts with several G $\alpha$ proteins (Berman et al. 1996, Watson et al. 1996, Hepler et al. 1997, Roy et al. 2003), including $G \alpha_{\mathrm{q} / 11}$ which is the G $\alpha$ subclass that has been implicated in Ang II receptor signal transduction (Spat \& Hunyady 2004). RGS4 proteins have been studied in several tissues, including the cardiovascular and nervous systems where it plays very important roles (Riddle et al. 2005). In the cardiovascular system, RGS4 levels were reported to be increased in the hearts of pulmonary artery-banded mice and in a rat model of genetic congestive heart failure (Zhang et al. 1998), as well as in failing human hearts (Owen et al. 2001, Mittmann et al. 2002). In vitro, RGS4 overexpression inhibits phenylephrine and endothelin-1-mediated induction of atrial natriuretic factor and myosin light chain-2 genes (Tamirisa et al. 1999) and attenuates sphingosine 1-phosphate receptor signaling (Cho et al. 2003). In vivo, RGS4 overexpression in ventricular tissue impairs the ability of the heart to adapt to acute ventricular pressure overload and cardiac hypertrophy caused by transverse aortic constriction (Rogers et al. 1999). Cardiac RGS4 is involved in diabetic cardiomyopathy since its overexpression confers resistance to streptozotocin-induced cardiac fetal gene induction (Harris et al. 2004). In the nervous system, RGS4 is also highly expressed and regulated by physiological and pharmacological agents (Ingi \& Aoki 2002, Neubig \& Siderovski 2002, Larminie et al. 2004). RGS4 mRNA levels are consistently decreased in the prefrontal cortex of schizophrenic patients (Mirnics et al. 2001). Linkage analysis studies indicated that several nucleotide polymorphisms in the RGS4 promoter region may be associated with schizophrenia (Chowdari et al. 2002, Morris et al. 2004), although more studies are required to confirm these associations (O'Donovan et al. 2003).

We hypothesize that genes preferentially/exclusively expressed in the rat adrenal zona glomerulosa may be involved in specific responses to proliferation and steroidogenesis of this adrenal gland zone. We used differential display to screen for these genes and observed that RGS4 was preferentially expressed in the rat adrenal zona glomerulosa. Since no studies have been reported regarding RGS4 expression and role in the adrenal cortex, we have conducted further studies to analyze RGS4 expression, regulation, and function in adrenocortical cells. We performed detailed analysis of RGS4 expression in rat adrenal gland and analyzed its regulation by salt diet intake manipulation and Ang II infusion in vivo. We also studied RGS4 regulation, the intracellular signaling mechanisms involved, and its role in aldosterone secretion using the H295R human adrenal cell line as our in vitro experimental model.

\section{Materials and Methods}

\section{Materials}

Ang II was obtained from Sigma Chemical Co. Ionomycin, nifedipine, SKF-96365 (SKF), calmidazolium, KN-93, autocamtide-2 cell permeable inhibitory peptide, phorbol-12myristate-13-acetate (PMA), bisindolylmaleimide I (GF 109203X), calphostin C, chelerythrine, Gö 6976, Gö 6983, Ro-31-8220, Ro-32-0432, and myristoylated protein kinase C (PKC) inhibitor peptide (20-28) were obtained from EMD Biosciences (San Diego, CA, USA). W-7 and STO-609 were obtained from Tocris (Ellisville, MO, USA). Merck Laboratories generously provided Losartan. Human adrenal total RNA was obtained from several sources: hAd1 (59-year-old male donor) from BioChain Institute Inc. (Hayward, CA, USA), hAd2 (pooled from $61 \mathrm{male} /$ female Caucasian donors, ages 15-61) from BD Biosciences (Mountain View, CA, USA), and hAd3 (30-year-old female donor) from Stratagene (La Jolla, CA, USA).

\section{Animals}

All animal protocols were approved by the Institutional Animal Care and Use Committee of the G V Montgomery VA Medical Center and by the Central Office of the Department of Veterans Affairs. Animal use and husbandry were in accordance with the National Institutes of Health Guide for the Care and Use of Laboratory Animals, and conducted in AAALAC-accredited facilities.

Male Sprague-Dawley rats (3 months old) were obtained from Harlan Sprague-Dawley (Indianapolis, IN, USA) and maintained on standard rat chow (Teklad, Harlan, Indianapolis, IN, USA) and tap water in an environment with $12 \mathrm{~h}$ light:12 h darkness cycles.

Salt diet manipulation Rats ( $n=6$ per group) were fed ad libitum a standard normal salt diet $(0 \cdot 3 \% \mathrm{NaCl}$; Teklad, Harlan, Madison, WI, USA), low-salt diet $(0 \cdot 03 \% \mathrm{NaCl})$, or high-salt diet (standard chow plus $0.9 \%$ saline to drink) for 2 or 15 days.

Ang II infusion Rats ( $n=6$ per group) were anesthetized by isoflurane gas and a catheter was placed in the femoral vein. The catheter was exteriorized at the back of the neck and rats were allowed to recover for 2 days. Conscious unrestrained rats were connected to an infusion pump and infused for 2 or $6 \mathrm{~h}$ with Ang II in saline at a dose of $100 \mathrm{ng} / \mathrm{kg}$ per min at rate of $500 \mu \mathrm{l} / \mathrm{h}$. Control rats received saline.

At the end of the experimental protocols, rats were anesthetized with isoflurane, adrenal glands removed, excised of fat, flash frozen in liquid nitrogen, and stored at $-80^{\circ} \mathrm{C}$.

\section{Northern blot}

Northern blots were performed as previously described (Zhou et al. 1995) with the following modifications. Nine 
micrograms of total RNA from capsule and core fractions of rat adrenal gland were separated by formaldehyde/formamide denaturing electrophoresis and transferred to Zeta Probe GT nylon membrane (Bio-Rad). PCR products were labeled using the Strip-EZ DNA kit (Ambion, Austin, TX, USA). Membranes were exposed to autoradiography film. Films were scanned and quantified with a Kodak Image Station 440 using the 1D Kodak image analysis software. Membranes were stripped and reprobed with GAPDH as loading control.

\section{In situ hybridization}

In situ hybridizations were performed as we previously described (Wotus et al. 1998, Daido et al. 2003) using the Sure-Site kit (EMD Biosciences) with the following modifications. Sections were washed once with $2 \times$ SSC for $30 \mathrm{~min}$ at $55^{\circ} \mathrm{C}$ followed by one wash in $1 \times$ SSC plus one more in $0.5 \times \mathrm{SSC}$ under similar conditions. Sections were air-dried and exposed to autoradiography film. Films were scanned with a Kodak Image Station 440.

\section{Cell culture}

H295R human adrenocortical cells (Bird et al. 1993) were cultured in H295R complete medium containing Dulbecco's modified Eagle's medium (DMEM):F12 (1:1) supplemented with 2\% Ultroser G (Biosepra, Villeneuve-la-Garenne, France), Insulin/Transferrin/Selenium-Plus (Discovery Labware, Bedford, MA, USA), and antibiotic/antimycotic mixture (Invitrogen) as we previously described (Romero et al. 2004), until subconfluent in 6-well plates. Medium was replaced with $3 \mathrm{ml}$ fresh medium containing various agents and cultured for $3 \mathrm{~h}$ more unless otherwise indicated. At the end of the incubation period, medium was removed and saved for steroid determination. To study the intracellular signaling pathways involved in RGS4 regulation, we used several inhibitors of the calcium/calmodulin/calmodulin-dependent protein kinase (CaMK) and PKC pathways (detailed in the Results section) which were added $30 \mathrm{~min}$ before Ang II addition. Reference sources used to select the inhibitor concentration used are indicated in Supplementary material Table 1(see supplementary data in the online version of the Journal of Endocrinology at http://joe.endocrinology -journals.org/content/vol 194/issue 2); preference was given to previous reports in the following order: (1) H295R cells, (2) other adrenocortical cell systems, (3) other cell systems.

\section{RNA extraction and RT-PCR}

Adrenal gland total RNA was extracted with Tri-Reagent (MRC, Cincinnati, OH, USA), resuspended in diethyl pyrocarbonate-treated $\mathrm{H}_{2} \mathrm{O}$, DNase treated with Turbo DNA-free kit (Ambion). H295R cell total RNA was extracted with the RNeasy Micro kit (Qiagen) and on-column DNase digested. For RT, $5 \mu \mathrm{g}$ total RNA was incubated with $0.5 \mu \mathrm{g}$ $\mathrm{T}_{12} \mathrm{VN}$ and Superscript III (Invitrogen) following the manufacturer's suggested protocol. Primers were designed with Primer3 software (Rozen \& Skaletsky 2000) and are shown in Table 1. Real-time PCR was performed with $1 \mu \mathrm{RT}$ product, $1 \mu \mathrm{l}$ titanium Taq DNA polymerase (Clontech), 1:20000 dilution SYBR Green I (Molecular Probes, Carlsbad, CA, USA), $0 \cdot 2 \mathrm{mM}$ dNTPs, and $0 \cdot 1 \mu \mathrm{M}$ of each primer. Cycling conditions were $1 \mathrm{~min}$ at $95^{\circ} \mathrm{C}, 50$ cycles of 15 s at $95^{\circ} \mathrm{C}, 15 \mathrm{~s}$ at $60{ }^{\circ} \mathrm{C}$, and $1 \mathrm{~min}$ at $72{ }^{\circ} \mathrm{C}$. Real-time data were obtained during the extension phase and threshold cycle values were obtained at the $\log$ phase of each gene amplification. PCR product quantification was performed by the relative quantification method (Pfaffl 2001) and standardized against GAPDH. Efficiency for each primer pair was assessed by using serial dilutions of RT product. Results are expressed as arbitrary units and normalized against GAPDH mRNA expression. The specificity of the PCR products was confirmed by melting temperature determination of the PCR product, and restriction enzyme digestion followed by high-resolution electrophoretic analysis in 4\% NuSieve 3:1 agarose gels (Cambrex, Rockland, ME, USA) of PCR products (Supplementary Fig. 1; (see supplementary data in the online version of the Journal of Endocrinology at http://joe.endocrinology-journals.org/ content/vol 194/issue 2)).

\section{Plasmids}

pGEM-T (Promega) plasmid carrying a fragment of rat RGS4 mRNA (bases 1397-2919 from NM_017214) was

Table 1 Real-time PCR primers

\begin{tabular}{|c|c|c|c|}
\hline & Accession number & Primers & Product size $(b p)$ \\
\hline \multicolumn{4}{|l|}{ Gene } \\
\hline \multirow[t]{2}{*}{ Rat RGS4 } & NM_017214 & Forward 5'-CAGGCAACAAAAGAGGTGGAAC-3' & 100 \\
\hline & & Reverse $5^{\prime}$-TCTTCTGGGCTTCATCAAAAC- $3^{\prime}$ & \\
\hline \multirow[t]{2}{*}{ Rat GAPDH } & NM_017008 & Forward 5'-AAGATGGTGAAGGTCGGTGT-3' & 99 \\
\hline & & Reverse 5'-GTTGATGGCAACAATGTCCACT-3' & \\
\hline \multirow{2}{*}{ Human RGS4 } & NM_005613 & Forward 5'-CTGCAAAAATCTGATTCCTGTG-3' & 100 \\
\hline & & Reverse $5^{\prime}$-CССАТTTCTTGАСТТССТСТTG-3' & \\
\hline \multirow[t]{2}{*}{ Human GAPDH } & NM_002046 & Forward $5^{\prime}$-CCСCTTCATTGACCTCAACTAC- $3^{\prime}$ & 103 \\
\hline & & Reverse 5'-GATGACAAGCTTCCCGTTCTC-3' & \\
\hline
\end{tabular}


used for probe generation for northern blot or in situ hybridization. A plasmid containing the human RGS4 insert in pDNR-1r was obtained from the University of Missouri at Rolla cDNA Resource Center (www.cdna. org). RGS4 was transferred from $\mathrm{pDNR}-1 \mathrm{r}$ to the retroviral BD Creator acceptor vector pLP-LNCX using the manufacturer's suggested protocol. The pVSV-G plasmid was purchased from Clontech.

\section{Retroviral production and infection}

VSV-G-pseudotyped retroviral particles were generated by transient transfection in GP2-293 cells as previously described (Romero et al. 2006). GP2-293 cells (Clontech) were cultured in DMEM supplemented with $10 \%$ fetal bovine serum until 60 $70 \%$ confluent, then transfected with retroviral vector and pVSV-G plasmids $\left(0 \cdot 25 \mu \mathrm{g} / \mathrm{cm}^{2}, 1: 1\right.$ molar ratio) using TransIT 293 transfection reagent $(2 \mu \mathrm{l} / \mu \mathrm{g}$ DNA, Mirus Bio, Madison, WI, USA). Medium was replaced after $4 \mathrm{~h}$ and cells cultured for an additional $48 \mathrm{~h}$. Cell culture supernatant was removed, centrifuged for $5 \mathrm{~min}$ at $200 \mathrm{~g}$ at $4{ }^{\circ} \mathrm{C}$, filtered through a $0.45 \mu \mathrm{m}$ polyether sulfone (PES) membrane, aliquoted, and stored at $-80{ }^{\circ} \mathrm{C}$. For retroviral infection, confluent H295R cells were split 1:3 in 6-well plates and cultured overnight. Retroviral supernatant was diluted 1:1 with fresh medium, added to cells, and cultured for $24 \mathrm{~h}$. Medium was replaced and cells were selected with $500 \mu \mathrm{g} / \mathrm{ml} \mathrm{G}$-418. Infection efficiency was more than $80 \%$ of the cell population. After antibiotic selection, cells were cultured for at least 4 weeks in the absence of selecting agent before performing the experiments to avoid any confounding effect due to the selecting antibiotic.

\section{Aldosterone ELISA}

Aldosterone was measured in cell culture supernatants by ELISA using an MAB developed in our laboratory as previously described (Gomez-Sanchez et al. 1987). Assay sensitivity was $20 \mathrm{pg} / \mathrm{ml}$.

\section{Statistical analysis}

All results were expressed as mean \pm s.E.M. Two groups were compared by $t$-test and multiple groups were analyzed by one-way ANOVA followed by Tukey's post hoc comparisons or two-way ANOVA followed by Bonferroni comparisons. Time-response curves were tested by two-way ANOVA followed by Bonferroni comparisons. Dose-response curves were adjusted to a four-parameter sigmoidal equation and its parameters tested by F-test; values were tested by two-way ANOVA followed by Bonferroni comparisons. All experiments were repeated at least twice in triplicates. Differences were considered statistically significant at $P<0 \cdot 05$. Statistical calculations were performed with Graphpad Prism package version 4.03 (Graphpad Software Inc., San Diego, CA, USA).

\section{Results}

RGS4 is expressed in the rat adrenal zona glomerulosa

To confirm our initial observation that RGS4 was preferentially expressed in the rat adrenal zona glomerulosa, we performed northern blot and in situ studies in the rat adrenal gland. We performed a northern blot using the capsule (outer cortex comprising zona glomerulosa and some zona fasciculata) and core (internal cortex and medulla) of the rat adrenal gland. RGS4 was preferentially expressed in the capsule fraction with negligible amounts observed in the core fraction (Fig. 1A). Membranes were stripped and reprobed with a GAPDH probe as an internal loading control to ensure that similar RNA amounts were loaded in each lane.

To more precisely localize RGS4 expression in the rat adrenal gland, we performed an in situ hybridization with a homologous rat RGS4 probe. RGS4 mRNA expression was localized in the zona glomerulosa of rat adrenal gland (Fig. 1B). The negative control sense probe showed no signal (Fig. 1B), indicating the specificity of the antisense RGS4 probe.

\section{RGS4 is regulated by salt intake in rat adrenal}

One of the main physiological modulators of adrenal gland zona glomerulosa physiology is salt intake. To study whether salt intake regulates RGS4 expression in adrenal gland, rats were placed on low- or high-salt diet for 2 or 15 days and RGS4 mRNA quantified in adrenal glands by real-time RT-PCR. Low-salt diet caused a continuous increase in adrenal gland
A

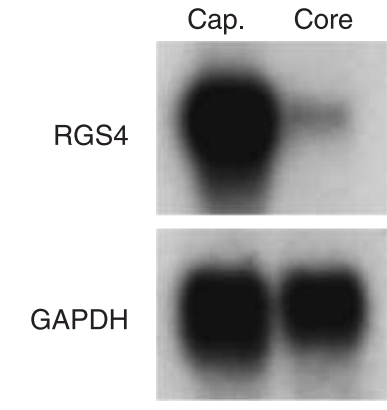

B

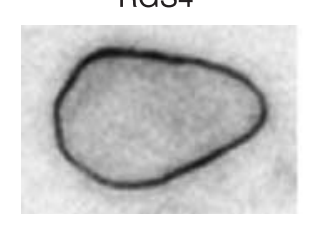

Control

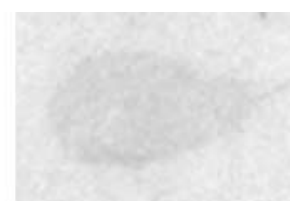

Figure 1 RGS4 expression in rat adrenal gland. (A) Rat adrenal glands were separated into capsules and coarse for RGS4 and GAPDH mRNA expression analysis by northern blot. (B) Rat adrenal gland sections were probed with a RGS4 antisense probe or a sense control probe by in situ hybridization. Representative figures from experiments repeated at least six times. 
RGS4 mRNA expression reaching a $66 \%$ increase after 15 days of treatment $(1 \cdot 01 \pm 0 \cdot 08$ vs $1 \cdot 66 \pm 0 \cdot 17, P<0 \cdot 05$; Fig. $2 A)$. In contrast, high-salt diet did not modify RGS4 mRNA levels up to 15 days of treatment.

\section{RGS4 is regulated by Ang II infusion in rat adrenal}

To study whether Ang II, a well-known aldosterone secretagogue and modulator of adrenal zona glomerulosa physiology, regulates RGS4 expression in adrenal gland, rats were infused with Ang II. Conscious chronically catheterized rats were infused with Ang II for 2 or 6 h, and adrenal RGS4 mRNA was quantified by real-time RT-PCR. Ang II infusion caused an increase in RGS4 mRNA expression reaching a $131 \%$ increase after $6 \mathrm{~h}$ of treatment $(1 \cdot 00 \pm 0 \cdot 10$ vs $2 \cdot 31 \pm 0 \cdot 34, P<0 \cdot 05$; Fig. $2 \mathrm{~B}$ ).

\section{RGS4 is upregulated by Ang II in H295R cells}

To further study the molecular mechanisms involved in the regulation and role of RGS4 in aldosterone secretion by adrenal
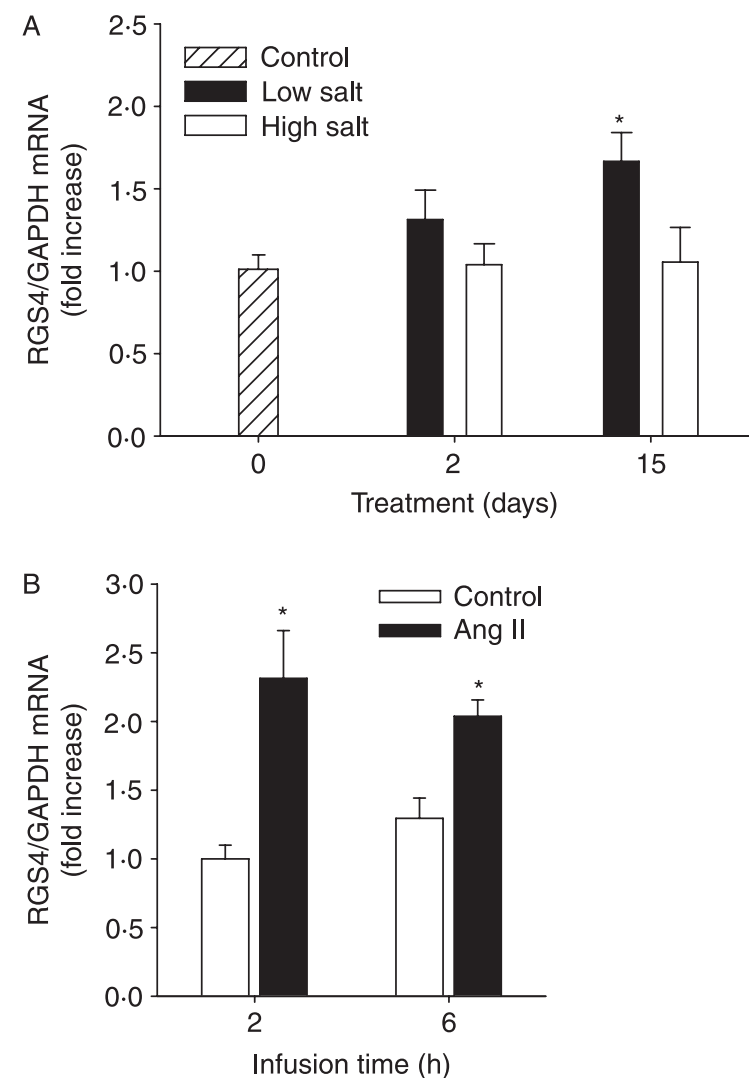

Figure 2 RGS4 mRNA expression regulation by sodium diet (A) or angiotensin II infusion (B). Rats were placed on low or high sodium diets for 2 or 15 days (A) or infused with $100 \mathrm{ng} / \mathrm{kg}$ per min angiotensin II for 2 or $6 \mathrm{~h}$ (B). Adrenal glands were removed and RGS4 mRNA quantified by real-time RT-PCR. ${ }^{*} P<0 \cdot 05$ versus rats in control $\operatorname{diet}(\mathrm{A})$ or versus rats infused with saline (B), $n=6$ per group. cells, H295R human adrenocortical cells were used as the experimental in vitro model. It is the only adrenal cell line that expresses all of the steroidogenic enzymes required for the synthesis of aldosterone from cholesterol and has a steroid secretion pattern and regulation similar to that of primary adrenal cell cultures (Rainey et al. 1994, 2004). H295R adrenocortical cells, as well as normal human adrenal glands, expressed RGS4 mRNA as detected by agarose gel electrophoresis of PCR products (Fig. 3A). Controls with no reverse transcriptase showed no amplification. GAPDH was used as a housekeeping control gene.

To determine whether RGS4 mRNA levels are subjected to regulation by Ang II in H295R cells as in rat adrenal glands, H295R human adrenocortical cells were incubated with $100 \mathrm{nM}$ Ang II for increasing periods up to $72 \mathrm{~h}$ and RGS4 mRNA expression was quantified by real-time PCR (Fig. 3B). Ang II caused a 25-fold increase in RGS4 mRNA levels $3 \mathrm{~h}$ after hormone stimulation. RGS4 mRNA then declined to basal levels within $24 \mathrm{~h}$ and remained suppressed for up to $72 \mathrm{~h}$ after the initiation of Ang II treatment. When H295R cells were treated with Ang II for shorter periods, it was observed that RGS4 mRNA levels reached maximal stimulation after 4-h treatment (Fig. 3C). To study the effect of different doses of Ang II on RGS4 mRNA expression, H295R cells were incubated with increasing concentrations of Ang II for $3 \mathrm{~h}$ and RGS4 mRNA quantified (Fig. 3D). Ang II $(0 \cdot 1-1000 \mathrm{nM})$ dose dependently increased RGS4 mRNA levels. To confirm the specificity of Ang II treatment on RGS4 mRNA regulation, H295R cells were treated with the Ang II receptor type 1 (AT1-R) blocker losartan $(10 \mu \mathrm{M})$ in the presence or absence of Ang II (10 nM) for $30 \mathrm{~min}$ (Fig. 3E). Losartan completely abolished (98\% inhibition) Ang II-mediated RGS4 mRNA upregulation, indicating that AT1-R specifically mediates RGS4 mRNA regulation by Ang II. The CaMK and PKC pathways are primary mediators of Ang II intracellular signaling in adrenal cells (Barrett et al. 1989, Ganguly \& Davis 1994, Bassett et al. 2004, Spat \& Hunyady 2004). To determine whether either of these pathways is involved in the regulation of RGS4 mRNA expression in H295R cells, we performed the following studies.

\section{Calcium signaling is involved in Ang II-mediated RGS4 upregulation in H295R cells}

To analyze whether calcium channel blocking would alter Ang II-mediated RGS4 upregulation, H295R cells were preincubated with the L-type $\mathrm{Ca}^{2+}$ channel selective blocker nifedipine before Ang II stimulation (Fig. 4A). Nifedipine caused a 55\% decrease in Ang II-mediated RGS4 upregulation $(100 \cdot 0 \pm 8 \cdot 9$ vs $45 \cdot 1 \pm 2 \cdot 0, P<0 \cdot 05)$.

To verify the involvement of calcium signaling on RGS4 mRNA upregulation, H295R cells were preincubated with SKF, an inhibitor of both receptor-mediated and voltagegated calcium influx entry (Merritt et al. 1990), before Ang II stimulation. SKF caused a 36\% decrease in Ang II-mediated 
A

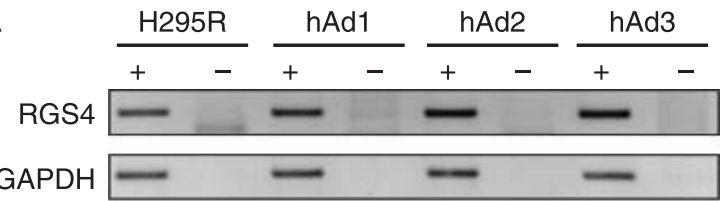

B

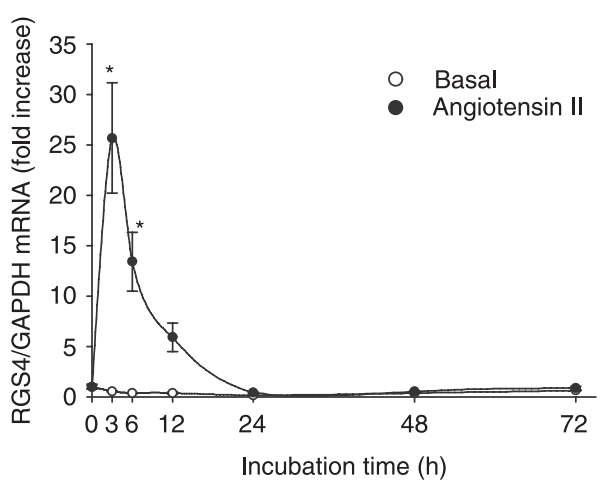

C

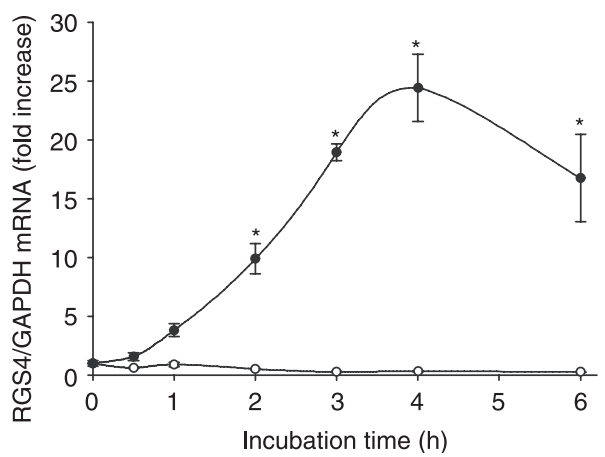

$\mathrm{D}$

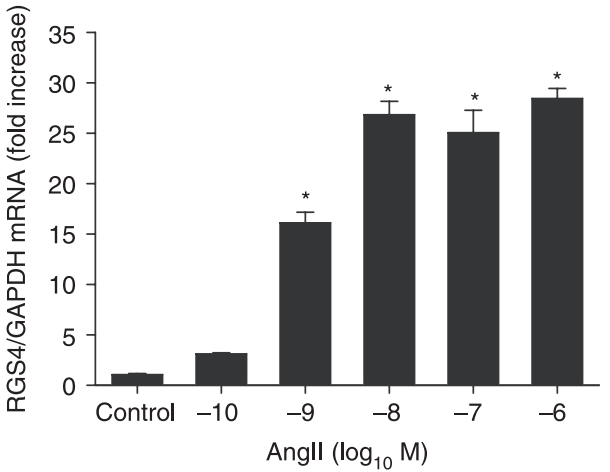

$\mathrm{E}$

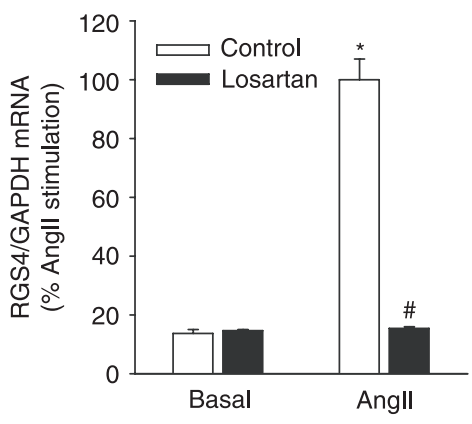

Figure 3 RGS4 expression and regulation in H295R cells. (A) RGS4 mRNA expression in H295R cells and human adrenal glands detected by agarose gel electrophoresis of RT-PCRs in the presence $(+)$ or absence $(-)$ of reverse transcriptase. GAPDH mRNA expression was used as control. hAd1: 59-year-old male donor, hAd2: pooled from 61 male/female white donors, ages 15-61, hAd3: 30-year-old female donor. (B and C) H295R cells were incubated with or without $100 \mathrm{nM}$ angiotensin II for 0-72 $\mathrm{h}$ (B) or 0-6 h (C) periods, RNA extracted, and then quantified by real-time RT-PCR. RGS4 mRNA was normalized by GAPDH mRNA expression and expressed as fold increase versus time $=0$. ${ }^{*} P<0.05$ versus basal, $n=3$. (D) H295R cells were incubated with increasing concentrations of Ang II for $3 \mathrm{~h}$, RNA extracted, and then quantified by real-time RT-PCR. RGS4 mRNA was normalized by GAPDH mRNA expression and expressed as fold increase versus time $=0 .{ }^{*} P<0 \cdot 05$ versus control, $n=3$. (E) H295R cells were treated with $10 \mu \mathrm{M}$ losartan or vehicle (control) for $30 \mathrm{~min}$ and then incubated in the presence or absence of angiotensin II (Ang II, $10 \mathrm{nM}$ ) for $3 \mathrm{~h}$, RNA extracted, and then quantified by real-time RT-PCR. RGS4 mRNA was normalized by GAPDH mRNA expression and expressed as percentage of angiotensin II stimulation. ${ }^{*} P<0 \cdot 05$ versus basal-control, ${ }^{\#} P<0 \cdot 05$ versus Ang II-Control, $n=3$.

RGS4 mRNA upregulation $(100 \cdot 0 \pm 7 \cdot 6$ vs $63 \cdot 4 \pm 6 \cdot 4$, $P<0 \cdot 05$; Fig. 4B).

Furthermore, when H295R cells were incubated with the calcium ionophore ionomycin $(1 \mu \mathrm{M})$ for $3 \mathrm{~h}$, RGS4 mRNA levels were increased $2 \cdot 1$-fold when compared with control cells $(1 \cdot 00 \pm 0 \cdot 12$ vs $2 \cdot 17 \pm 0 \cdot 29, P<0 \cdot 05)$.
Calmodulin and CaMKK/CaMK mediates RGS4 mRNA upregulation by Ang II in H295R cells

Calcium mediates most of its biological effects through binding to the calcium-binding protein, calmodulin, causing a conformational change allowing calmodulin to interact and 

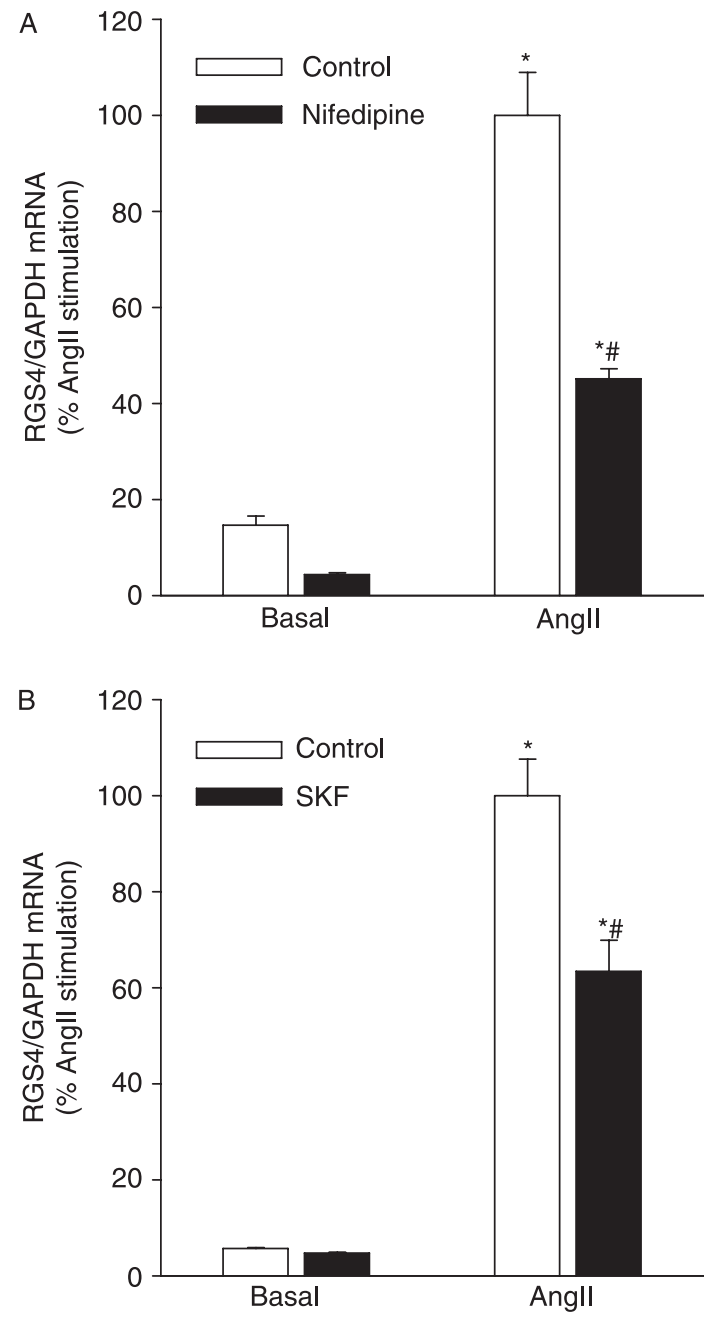

Figure 4 Effect of $\mathrm{Ca}^{2+}$ channel blockers on RGS4 mRNA expression. H295R cells were treated with $10 \mu \mathrm{M}$ nifedipine (A), $25 \mu \mathrm{M}$ SKF (B), or vehicle for $30 \mathrm{~min}$ and then incubated in the presence or absence of angiotensin II (Ang II, $100 \mathrm{nM}$ ) for $3 \mathrm{~h}$. RNA was extracted and then quantified by real-time RT-PCR. RGS4 mRNA was normalized by GAPDH mRNA expression and expressed as fold increase or percentage of angiotensin II stimulation. ${ }^{*} P<0 \cdot 05$ versus basal-control, ${ }^{\sharp} P<0 \cdot 05$ versus control for its treatment, $n=3$.

modify the activity of its target proteins. We studied the effect of two calmodulin antagonists, W-7, and calmidazolium, on basal and stimulated conditions. W-7 and calmidazolium caused a $66 \%(100 \cdot 0 \pm 4 \cdot 4$ vs $44 \cdot 1 \pm 1 \cdot 5, P<0 \cdot 05)$ and $67 \%$ $(100 \cdot 0 \pm 4 \cdot 4$ vs $32 \cdot 8 \pm 1 \cdot 36, P<0 \cdot 05)$ decrease respectively in Ang II-mediated RGS4 mRNA induction (Fig. 5A).

Once complexed with calcium, calmodulin can interact with calmodulin kinases (CaMK), allowing phosphorylation of the inhibitory subunit by CaMK regulatory subunit and causing activation of the protein kinase. CaMK kinase $(\mathrm{CaMKK})$ is an upstream regulator of CaMK that is also
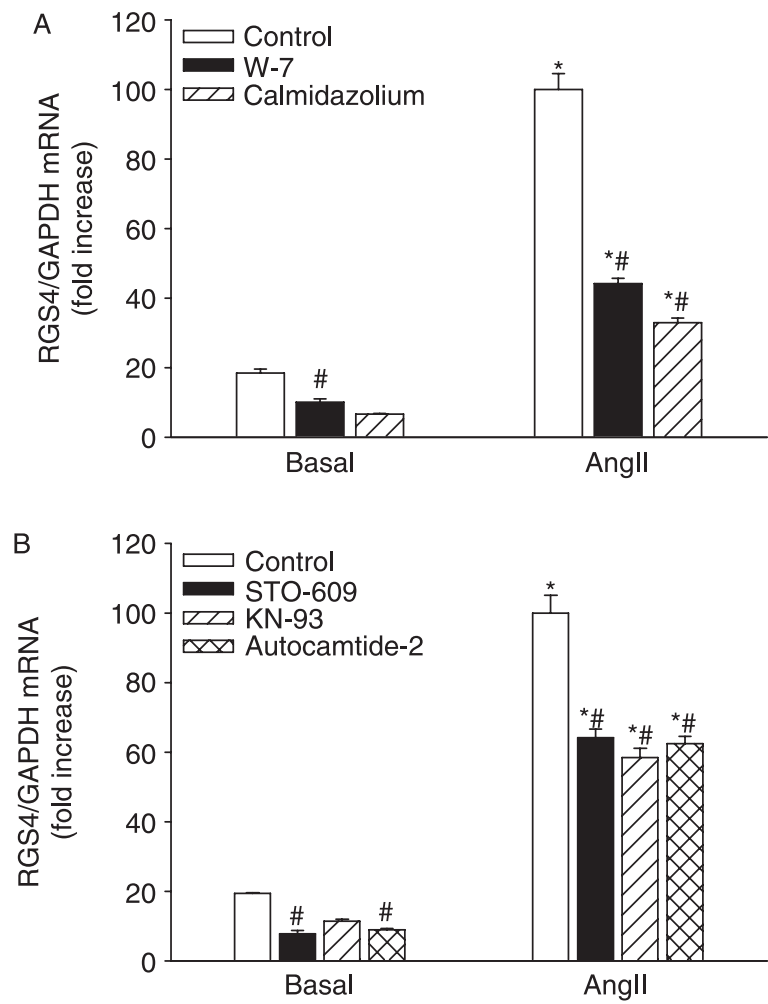

Figure 5 Effect of calmodulin antagonists and CaMKK and CaMK inhibitors on RGS4 expression. H295R cells were treated with $50 \mu \mathrm{M} \mathrm{W}-7$ (A), $10 \mu \mathrm{M}$ calmidazolium (A), $1 \mu \mathrm{g} / \mathrm{ml}$ STO-609 (B), $5 \mu \mathrm{M} \mathrm{KN}-93$ (B), $10 \mu \mathrm{M}$ autocamtide-2 (B), or vehicle for $30 \mathrm{~min}$ and then incubated in the presence or absence of angiotensin II (Ang II, $100 \mathrm{nM}$ ) for $3 \mathrm{~h}$. RNA was extracted and then quantified by real-time RT-PCR. RGS4 mRNA was normalized by GAPDH mRNA expression and expressed as percentage of Angiotensin II stimulation. ${ }^{*} P<0 \cdot 05$ versus basal-control, ${ }^{\sharp} P<0 \cdot 05$ versus control for its treatment, $n=3$.

regulated by calmodulin. CaMKs are expressed in the adrenal gland and are among the main effectors of calcium intracellular signaling in this gland (Barrett et al. 1989, Ganguly \& Davis 1994, Condon et al. 2002). Pretreatment of H295R cells with the CaMKK-specific inhibitor STO-609 caused a 36\% decrease in Ang II-mediated RGS4 mRNA induction $(100 \cdot 0 \pm 5 \cdot 1$ vs $64 \cdot 0 \pm 2 \cdot 6, P<0 \cdot 05$; Fig. $5 \mathrm{~B})$.

To analyze whether CaMK mediates RGS4 mRNA induction, H295R cells were pretreated with the CaMK-specific inhibitors KN-93 or autocamtide-2. Both KN-93 and autocamtide- 2 caused a $42 \%(100 \cdot 0 \pm 5 \cdot 1$ vs $58 \cdot 5 \pm 2 \cdot 6, P<0 \cdot 05)$ and $38 \%(100 \cdot 0 \pm 5 \cdot 1$ vs $62 \cdot 4 \pm 2 \cdot 0, P<0 \cdot 05)$ decrease respectively in Ang II-mediated RGS4 mRNA induction (Fig. 5B).

PKC mediates Ang II-mediated RGS4 $m R N A$ upregulation in H295R cells

To study the role of PKC in RGS4 mRNA upregulation, we performed experiments involving activation and inhibition of 
this protein kinase. Incubation of $\mathrm{H} 295 \mathrm{R}$ cells with increasing concentrations of the PKC activator PMA caused a dosedependent increase in RGS4 mRNA levels, reaching maximum levels at $100 \mathrm{nM}$ PMA $(23 \cdot 65 \pm 0 \cdot 63$ vs $1 \cdot 00 \pm 0 \cdot 05, P<0 \cdot 05$; Fig. 6A). Since exogenous activation of PKC increases RGS4 mRNAlevels, we studied whether PKC inhibitors could modify Ang II-mediated RGS4 mRNA upregulation. The generic PKC inhibitors bisindolylmaleimide I and Gö 6983 almost completely blocked Ang II-mediated R GS4 mRNA upregulation $(100 \cdot 0 \pm 3 \cdot 3$ vs $16 \cdot 4 \pm 0 \cdot 7, P<0 \cdot 05$, vs $8 \cdot 71 \pm 0 \cdot 3$,
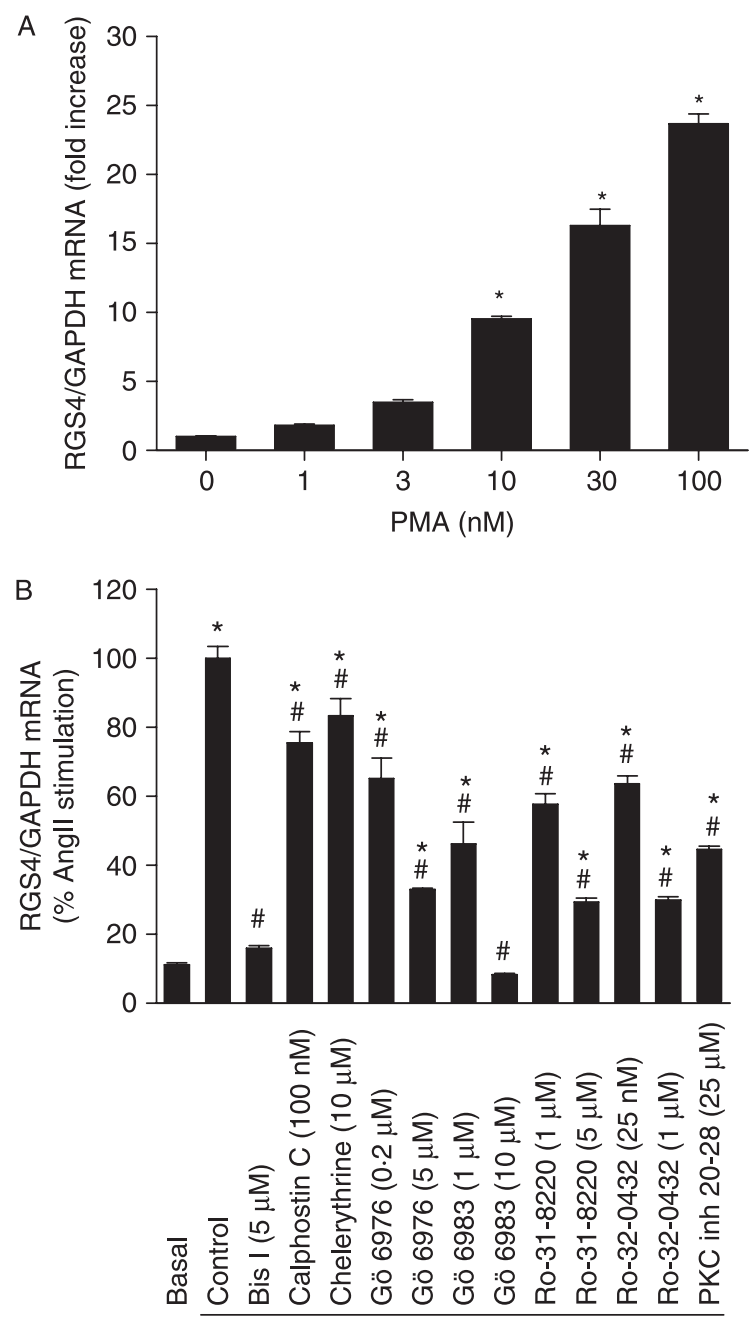

Angll (100 nM)

Figure 6 Effect of protein kinase C on RGS4 mRNA expression. $\mathrm{H} 295 \mathrm{R}$ cells were incubated with increasing concentrations of PKC activator PMA for $3 \mathrm{~h}(\mathrm{~A})$ or treated with different PKC inhibitors or vehicle for $30 \mathrm{~min}$ and then incubated in the presence or absence of angiotensin II (Ang II, $100 \mathrm{nM}$ ) for $3 \mathrm{~h}$ (B). RNA was extracted and then quantified by real-time RT-PCR. RGS4 mRNA was normalized by GAPDH mRNA expression and expressed as percentage of angiotensin II stimulation. ${ }^{*} P<0 \cdot 05$ versus control, ${ }^{\sharp} P<0 \cdot 05$ versus Ang II, $n=3$.
$P<0 \cdot 05$ respectively; Fig. 6B). Other PKC inhibitors, calphostin C, chelerythrine, Gö 6976, Ro-31-8220, Ro-320432, and the PKC inhibitory peptide (20-28) all decreased Ang II-mediated R GS4 mRNA upregulation (Fig. 6B), suggesting a critical role of PKC in RGS4 mRNA level modulation.

RGS4 overexpression decreased aldosterone secretion in H295R cells

To examine the effect of RGS4 upregulation on aldosterone secretion, we used retroviruses expressing RGS4 under control of the cytomegalovirus (CMV) promoter to generate H295R cells that stably overexpress RGS4 (H295R-RGS4 cells). H295R-RGS4 significantly overexpressed RGS4 mRNA $(P<0 \cdot 05$, Fig. 7 insert $)$. To study whether RGS4 overexpression alters aldosterone secretion in response to Ang II, H295R and H295R-RGS4 cells were incubated with increasing concentrations of Ang II, and the cell culture supernatants were assayed for aldosterone. RGS4 overexpression caused a significant decrease in aldosterone secretion at all doses of Ang II tested (Fig. 7). RGS4 overexpression reduced basal $(22 \cdot 3 \pm 4 \cdot 6$ vs $0 \cdot 38 \pm 1 \cdot 44$, $P<0 \cdot 05)$ and maximal stimulation $(108 \cdot 4 \pm 6 \cdot 7$ vs $50 \cdot 7 \pm$ $4 \cdot 3, P<0 \cdot 05)$ aldosterone secretion.

\section{Discussion}

In the present study, we demonstrate that: (1) RGS4 is expressed in the rat adrenal gland exclusively in the zona glomerulosa, (2) rat adrenal RGS4 mRNA is upregulated in vivo by low-salt diet intake and Ang II infusion, (3) RGS4 is expressed in H295R human adrenocortical cells and is

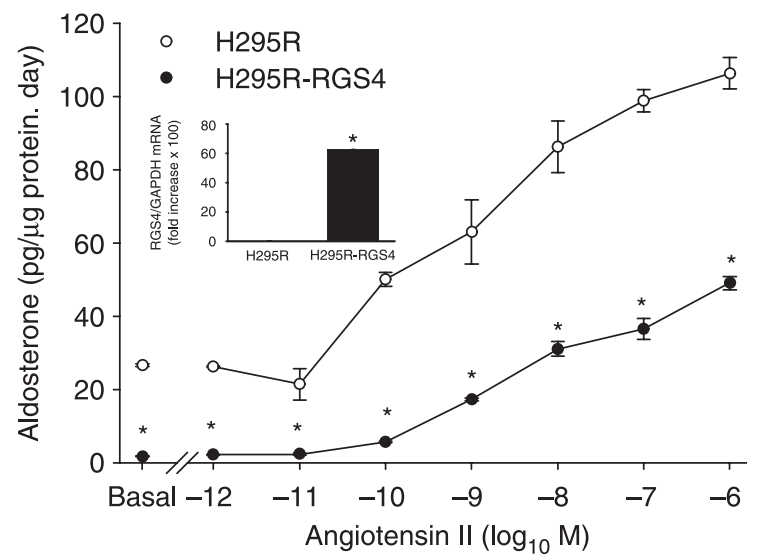

Figure 7 Effect of RGS4 overexpression on aldosterone secretion. H295R cells were infected with retroviruses expressing RGS4, selected, and incubated with increasing concentrations of Angiotensin II for $24 \mathrm{~h}$. Aldosterone concentration was measured in medium supernatant and cells lysed to quantify total protein. Insert shows RGS4 mRNA overexpression in H295R-RGS4 cells. $* P<0 \cdot 05$ versus control cells, $n=3$. 
upregulated by Ang II, (4) Ang II-mediated RGS4 mRNA upregulation in $\mathrm{H} 295 \mathrm{R}$ cells is mediated by the calcium/ calmodulin/CaMK and PKC pathways, and (5) RGS4 overexpression in $\mathrm{H} 295 \mathrm{R}$ cells caused a decrease in Ang II-mediated aldosterone secretion.

Hormonal signals are crucial for the functional integration of different organs and systems within living organisms. After binding to cognate receptors, hormones trigger a cascade of intracellular events that cause specific physiological responses. The termination of intracellular signaling events is as important as their initiation to achieve homeostasis at the cellular and whole organism level. Ang II modifies several aspects of adrenal cell metabolism and physiology including steroid secretion and zona glomerulosa cell proliferation. Ang II binds to its GPCRs, which interact with G-proteins, that upon exchange of GDP by GTP are activated and available to interact with target effector proteins to transduce the Ang II signal from the extracellular space to the intracellular compartment. Our results indicate that RGS4 is a gene in the adrenal gland that is exclusively expressed in the zona glomerulosa and whose expression is regulated in vivo by physiological modulators of zona glomerulosa cells, salt intake, and Ang II. RGS4 proved to be regulated by Ang II in H295R cells in vitro and its overexpression caused a decrease in Ang II-mediated aldosterone secretion. Since the main physiological function of RGS proteins is to increase the rate of $\mathrm{G} \alpha$ protein inactivation and consequently the downregulation of the intracellular signal triggered by the GPCR, RGS4 is probably crucial for the physiological termination of Ang II signal in adrenal cells, prevention of an exaggerated or prolonged Ang II signal, and promotion of homeostasis.

We have recently reported that Ang II upregulates RGS2 expression in H295R human adrenocortical cells and exerts similar physiological effects as RGS4 on adrenal steroidogenesis regulation (Romero et al. 2006). The regulation of RGS2 and RGS4 mRNA levels and the intracellular signaling pathways involved, although similar, are unique. Ang II caused a continuous increase in RGS4 mRNA levels up to $4 \mathrm{~h}$ after treatment, while RGS2 mRNA reached maximal stimulation levels within $1 \mathrm{~h}$ (Romero et al. 2006). These results agree with the few reports in which time-response curves of RGS2 and RGS4 mRNA levels were generated. Taymans et al. (2004) reported that dopamine receptor 2 blockade caused regulation of RGS2 and RGS4 mRNA levels in rat brain in opposite directions, with RGS4 mRNA levels upregulated more slowly than RGS2 levels. Although Ang II-mediated RGS4 mRNA upregulation in adrenal cells lags that of RGS2, the degree of stimulation is much higher reaching 25-fold when compared with only 5-fold for RGS2 (Romero et al. 2006). Both Ang II-mediated RSG4 and RGS2 mRNA upregulation are mediated by the calcium/ calmodulin/CaMKK/CaMK intracellular signaling pathway. However, PKC seems to be a key mediator in Ang II-mediated RGS4 mRNA upregulation, while this protein kinase does not seem to play a significant role in the regulation of RGS2 mRNA in H295R cells (Romero et al. 2006).

To study the role of RGS4 in Ang II-mediated aldosterone secretion, we overexpressed RGS4 in H295R cells. RGS4 overexpression caused a decrease in Ang II-mediated aldosterone production as well as in basal aldosterone secretion in the absence of added Ang II. This finding is not surprising since H295R cells, like adrenal zona glomerulosa cells in vivo, have an endogenous reninangiotensin system that generates Ang II under basal conditions promoting basal aldosterone secretion in the absence of exogenous stimuli (Hilbers et al. 1999). RGS4 overexpression in $\mathrm{H} 295 \mathrm{R}$ cells reduced maximal Ang II-mediated aldosterone secretion but did not modify the responsiveness of the system, since it did not modify Ang II $\mathrm{pEC}_{50}$ for aldosterone secretion. The effects of RGS4 overexpression on adrenal cell steroidogenesis are similar to those we previously reported for RGS2 (Romero et al. 2006). Although there was a significant increase in RGS4 mRNA levels in H295R-RGS4 overexpressing cells, the fact that RGS4 did not blunt Ang II-mediated steroidogenesis may indicate that this RGS protein may be necessary but not solely sufficient to turn off Ang II signaling in adrenal cells. Other cellular processes, such as Ang II signaling and Ang II receptor desensitization and downregulation, and Ang II receptor internalization are known to occur in H295R cells as well as adrenocortical cells in response to Ang II (Bianchi et al. 1986, Penhoat et al. 1988, Naville et al. 1993, Bird et al. 1994, Boulay et al. 1994, Ouali et al. 1997, Richard et al. 1997, Spat \& Hunyady 2004) and complement RGS4 role in the regaining of cellular homeostasis after Ang II stimulation.

Ang II upregulates RGS4 mRNA levels through the calcium/calmodulin/CaMKK/CaMK and PKC pathways. It has been reported that Ang II upregulates CaMK activity in bovine zona glomerulosa cells (Fern et al. 1995, Gambaryan et al. 2006). CaMK inhibitors inhibit Ang II-mediated aldosterone secretion (Denner et al. 1996, Gambaryan et al. 2006) and aldosterone synthase expression (Pezzi et al. 1997, Condon et al. 2002). More recently, it has been shown by cotransfection reporter assays that CaMKI may be the CaMK isoform involved in Ang II-mediated aldosterone synthase expression regulation (Condon et al. 2002). PKC negatively affects Ang II-mediated aldosterone secretion and aldosterone synthase expression (Bird et al. 1998, LeHoux \& Lefebvre 1998, Hajnoczky et al. 1992, LeHoux et al. 2001). PKC activators decrease and PKC inhibitors increase aldosterone synthase expression (Bird et al. 1998, LeHoux \& Lefebvre 1998, LeHoux et al. 2001). More recently, PKC $\varepsilon$ has been proposed to be the $\mathrm{PKC}$ isozyme involved in the regulation of aldosterone synthase in H295R cells (LeHoux \& Lefebvre 2006). RGS4 has a complex interaction with the intracellular signaling pathways that regulate its expression. While the calmodulin/CaMKK/CaMK signaling pathway is a positive modulator of aldosterone secretion and aldosterone synthase expression, it also upregulates RGS4 expression which then functions as a negative feedback of Ang II-mediated 
aldosterone secretion. On the other hand, the decrease in aldosterone secretion and aldosterone synthase expression produced by PKC may be mediated by its regulation of RGS4 expression. Perhaps, PKC activation decreases aldosterone secretion by upregulating RGS4 expression, thus terminating Ang II-mediated signaling that increases aldosterone synthesis.

A limitation of the present report is that RGS4 regulation was detected at the mRNA levels instead of the protein level. Endogenous RGS4 levels are very low and below the detection limit of currently available antibodies, as we have observed in rat adrenal gland and H295R cells, and as other researchers have reported in several other cell lines (Ingi et al. 1998). Plasmid-driven expression of RGS4 protein in mammalian cells have a half-life of only 45 min (Davydov \& Varshavsky 2000) due to its rapid degradation by the ubiquitin-dependent $N$-end rule pathway (Davydov \& Varshavsky 2000, Lee et al. 2005). The short half-life of RGS4 protein makes it very likely that RGS4 protein levels reflect those of its mRNA, and the determination of RGS4 mRNA levels are an achievable and valid extrapolation for the study of the regulation of RGS4 levels in adrenal cells.

In the present report, we show that RGS4 is zona glomerulosa-specific gene of adrenal gland, is upregulated by low sodium intake and Ang II, and is involved in adrenal cell aldosterone secretion regulation. These findings and our previous ones regarding RGS2 elucidate a new mechanism by which Ang II intracellular signaling is terminated and the Ang II receptor desensitized independently of Ang II receptor downregulation by internalization within the adrenal cell. We speculate that RGS2 and RGS4 are crucial for the regulation of aldosterone synthesis and that alteration in either their expression or activity due to loss or gain of function mutations may lead to abnormal adrenal GPCR signaling and aldosterone synthesis.

Aldosterone exerts its effect not only in epithelial target tissues, where its main function is regulation of sodium/ potassium and water balance, but also in non-epithelial tissues such as the brain and the heart. High aldosterone levels have been associated with severe target organ injury in the heart and the kidney of hypertensive patients with primary aldosteronism (Rossi et al. 1997, 2006, Tanabe et al. 1997). In addition, excess aldosterone in non-hypertensive patients has been reported to correlate with an increased risk to suffer an increase in blood pressure or develop hypertension (Vasan et al. 2004, Newton-Cheh et al. 2007). Alterations in Ang II-mediated aldosterone synthesis and secretion by the adrenal gland due to RGS4 alterations in its expression levels and/or activity may underlie or exacerbate deleterious effects of aldosterone caused by its excessive synthesis and secretion.

\section{Acknowledgements}

We thank Dr W E Rainey (Medical College of Georgia, Augusta, GA, USA) for generously providing reporter plasmids and H295R cells. We thank Gina S Covington for her excellent technical assistance.

\section{Funding}

This work was supported by Medical Research funds from the Department of Veterans Affairs and NIH grants HL27255 and HL75321. The authors declare that there is no conflict of interest that would prejudice the impartiality of this scientific work.

\section{References}

Abramow-Newerly M, Roy AA, Nunn C \& Chidiac P 2006 RGS proteins have a signalling complex: interactions between RGS proteins and GPCRs, effectors, and auxiliary proteins. Cellular Signalling 18 579-591.

Barrett PQ, Bollag WB, Isales CM, McCarthy RT \& Rasmussen H 1989 Role of calcium in angiotensin II-mediated aldosterone secretion. Endocrine Reviews 10 496-518.

Bassett MH, White PC \& Rainey WE 2004 The regulation of aldosterone synthase expression. Molecular and Cellular Endocrinology 217 67-74.

Berman DM \& Gilman AG 1998 Mammalian RGS proteins: barbarians at the gate. Journal of Biological Chemistry 273 1269-1272.

Berman DM, Kozasa T \& Gilman AG 1996 The GTPase-activating protein RGS4 stabilizes the transition state for nucleotide hydrolysis. Journal of Biological Chemistry 271 27209-27212.

Bianchi C, Gutkowska J, De Lean A, Ballak M, Anand-Srivastava MB, Genest J \& Cantin M 1986 Fate of [125I]angiotensin II in adrenal zona glomerulosa cells. Endocrinology 118 2605-2607.

Bird IM, Hanley NA, Word RA, Mathis JM, McCarthy JL, Mason JI \& Rainey WE 1993 Human NCI-H295 adrenocortical carcinoma cells: a model for angiotensin-II-responsive aldosterone secretion. Endocrinology 133 1555-1561.

Bird IM, Mason JI \& Rainey WE 1994 Regulation of type 1 angiotensin II receptor messenger ribonucleic acid expression in human adrenocortical carcinoma H295 cells. Endocrinology 134 2468-2474.

Bird IM, Mason JI \& Rainey WE 1998 Battle of the kinases: integration of adrenal responses to cAMP, DG and $\mathrm{Ca}^{2+}$ at the level of steroidogenic cytochromes P450 and 3 beta HSD expression in H295R cells. Endocrine Research 24 345-354.

Blumer KJ 2005 Rgs4. AfCS-Nature Molecule Pages doi:10.1038/mp.a000134.000101.

Boulay G, Chretien L, Richard DE \& Guillemette G 1994 Short-term desensitization of the angiotensin II receptor of bovine adrenal glomerulosa cells corresponds to a shift from a high to a low affinity state. Endocrinology 135 2130-2136

Burchett SA 2000 Regulators of G protein signaling: a bestiary of modular protein binding domains. Journal of Neurochemistry 75 1335-1351.

Cho H, Harrison K, Schwartz O \& Kehrl JH 2003 The aorta and heart differentially express RGS (regulators of G-protein signalling) proteins that selectively regulate sphingosine 1-phosphate, angiotensin II and endothelin-1 signalling. Biochemical Journal 371 973-980.

Chowdari KV, Mirnics K, Semwal P, Wood J, Lawrence E, Bhatia T, Deshpande SN, B KT, Ferrell RE, Middleton FA et al. 2002 Association and linkage analyses of RGS4 polymorphisms in schizophrenia. Human Molecular Genetics 11 1373-1380.

Condon JC, Pezzi V, Drummond BM, Yin S \& Rainey WE 2002 Calmodulin-dependent kinase I regulates adrenal cell expression of aldosterone synthase. Endocrinology 143 3651-3657.

Daido H, Zhou MY, Gomez-Sanchez EP \& Gomez-Sanchez CE 2003 Interferon-inducible genes in the rat adrenal gland and vascular smooth muscle cells. Molecular and Cellular Endocrinology 200 81-87. 
Davydov IV \& Varshavsky A 2000 RGS4 is arginylated and degraded by the $\mathrm{N}$-end rule pathway in vitro. Journal of Biological Chemistry 275 2293122941.

Denner K, Rainey WE, Pezzi V, Bird IM, Bernhardt R \& Mathis JM 1996 Differential regulation of 11 beta-hydroxylase and aldosterone synthase in human adrenocortical H295R cells. Molecular and Cellular Endocrinology 121 87-91.

Fern RJ, Hahm MS, Lu HK, Liu LP, Gorelick FS \& Barrett PQ 1995 $\mathrm{Ca}^{2+} /$ calmodulin-dependent protein kinase II activation and regulation of adrenal glomerulosa $\mathrm{Ca}^{2+}$ signaling. American Journal of Physiology 269 F751-F760.

Gambaryan S, Butt E, Tas P, Smolenski A, Allolio B \& Walter U 2006 Regulation of aldosterone production from zona glomerulosa cells by ANG II and cAMP: evidence for PKA-independent activation of CaMK by cAMP. American Journal of Physiology. Endocrinology and Metabolism 290 E423-E433.

Ganguly A \& Davis JS 1994 Role of calcium and other mediators in aldosterone secretion from the adrenal glomerulosa cells. Pharmacological Reviews 46 417-447.

Gomez-Sanchez CE, Foecking MF, Ferris MW, Chavarri MR, Uribe L \& Gomez-Sanchez EP 1987 The production of monoclonal antibodies against aldosterone. Steroids 49 581-587.

Hajnoczky G, Varnai P, Buday L, Farago A \& Spat A 1992 The role of protein kinase-C in control of aldosterone production by rat adrenal glomerulosa cells:activation of protein kinase-C by stimulation with potassium. Endocrinology 130 2230-2236.

Harris IS, Treskov I, Rowley MW, Heximer S, Kaltenbronn K, Finck BN, Gross RW, Kelly DP, Blumer KJ \& Muslin AJ 2004 G-protein signaling participates in the development of diabetic cardiomyopathy. Diabetes $\mathbf{5 3}$ 3082-3090.

Hepler JR, Berman DM, Gilman AG \& Kozasa T 1997 RGS4 and GAIP are GTPase-activating proteins for Gq alpha and block activation of phospholipase C beta by gamma-thio-GTP-Gq alpha. PNAS 94 428-432.

Hilbers U, Peters J, Bornstein SR, Correa FMA, Jöhren O, Saavedra JM \& Ehrhart-Bornstein M 1999 Local renin-angiotensin system is involved in $\mathrm{K}^{+}$-induced aldosterone secretion from human adrenocortical NCI-H295 cells. Hypertension 33 1025-1030.

Hollinger S \& Hepler JR 2002 Cellular regulation of RGS proteins: modulators and integrators of $\mathrm{G}$ protein signaling. Pharmacological Reviews $54527-559$.

Ingi T \& Aoki Y 2002 Expression of RGS2, RGS4 and RGS7 in the developing postnatal brain. European Journal of Neuroscience 15 929-936.

Ingi T, Krumins AM, Chidiac P, Brothers GM, Chung S, Snow BE, Barnes CA, Lanahan AA, Siderovski DP, Ross EM et al. 1998 Dynamic regulation of RGS2 suggests a novel mechanism in G-protein signaling and neuronal plasticity. Journal of Neuroscience 18 7178-7188.

Larminie C, Murdock P, Walhin JP, Duckworth M, Blumer KJ, Scheideler MA \& Garnier M 2004 Selective expression of regulators of G-protein signaling (RGS) in the human central nervous system. Brain Research. Molecular Brain Research 122 24-34.

Lee MJ, Tasaki T, Moroi K, An JY, Kimura S, Davydov IV \& Kwon YT 2005 RGS4 and RGS5 are in vivo substrates of the N-end rule pathway. PNAS 102 15030-15035.

LeHoux JG \& Lefebvre A 1998 Transcriptional activity of the hamster CYP11B2 promoter in NCI-H295 cells stimulated by angiotensin II, potassium, forskolin and bisindolylmaleimide. Journal of Molecular Endocrinology 20 183-191.

LeHoux JG \& Lefebvre A 2006 Novel protein kinase C-epsilon inhibits human CYP11B2 gene expression through ERK1/2 signalling pathway and JunB. Journal of Molecular Endocrinology 36 51-64.

LeHoux JG, Dupuis G \& Lefebvre A 2001 Control of CYP11B2 gene expression through differential regulation of its promoter by atypical and conventional protein kinase C isoforms. Journal of Biological Chemistry 276 8021-8028.

Merritt JE, Armstrong WP, Benham CD, Hallam TJ, Jacob R, Jaxa-Chamiec A, Leigh BK, McCarthy SA, Moores KE \& Rink TJ 1990 SK\&F 96365, a novel inhibitor of receptor-mediated calcium entry. Biochemical Journal 271 $515-522$.
Mirnics K, Middleton FA, Stanwood GD, Lewis DA \& Levitt P 2001 Diseasespecific changes in regulator of G-protein signaling 4 (RGS4) expression in schizophrenia. Molecular Psychiatry 6 293-301.

Mittmann C, Chung CH, Hoppner G, Michalek C, Nose M, Schuler C, Schuh A, Eschenhagen T, Weil J, Pieske B et al. 2002 Expression of ten RGS proteins in human myocardium: functional characterization of an upregulation of RGS4 in heart failure. Cardiovascular Research 55 778-786.

Morris DW, Rodgers A, McGhee KA, Schwaiger S, Scully P, Quinn J, Meagher D, Waddington JL, Gill M \& Corvin AP 2004 Confirming RGS4 as a susceptibility gene for schizophrenia. American Journal of Medical Genetics. Part B, Neuropsychiatric Genetics 125 50-53.

Naville D, Lebrethon MC, Kermabon AY, Rouer E, Benarous R \& Saez JM 1993 Characterization and regulation of the angiotensin II type-1 receptor (binding and mRNA) in human adrenal fasciculata-reticularis cells. FEBS Letters 321 184-188.

Neubig RR \& Siderovski DP 2002 Regulators of G-protein signalling as new central nervous system drug targets. Nature Reviews. Drug Discovery 1 187-197.

Newton-Cheh C, Guo CY, Gona P, Larson MG, Benjamin EJ, Wang TJ, Kathiresan S, O’Donnell CJ, Musone SL, Camargo AL et al. 2007 Clinical and genetic correlates of aldosterone-to-renin ratio and relations to blood pressure in a community sample. Hypertension 49 846-856.

O'Donovan MC, Williams NM \& Owen MJ 2003 Recent advances in the genetics of schizophrenia. Human Molecular Genetics 12 R125-R133.

Ouali R, Berthelon MC, Begeot M \& Saez JM 1997 Angiotensin II receptor subtypes AT1 and AT2 are down-regulated by angiotensin II through AT1 receptor by different mechanisms. Endocrinology 138 725-733.

Owen VJ, Burton PB, Mullen AJ, Birks EJ, Barton P \& Yacoub MH 2001 Expression of RGS3, RGS4 and Gi alpha 2 in acutely failing donor hearts and end-stage heart failure. European Heart Journal 22 1015-1020.

Penhoat A, Jaillard C, Crozat A \& Saez JM 1988 Regulation of angiotensin II receptors and steroidogenic responsiveness in cultured bovine fasciculata and glomerulosa adrenal cells. European Journal of Biochemistry 172 247-254.

Pezzi V, Clyne CD, Ando S, Mathis JM \& Rainey WE 1997 Ca(2+)regulated expression of aldosterone synthase is mediated by calmodulin and calmodulin-dependent protein kinases. Endocrinology 138 835-838.

Pfaffl MW 2001 A new mathematical model for relative quantification in realtime RT-PCR. Nucleic Acids Research 29 e45.

Rainey WE, Bird IM \& Mason JI 1994 The NCI-H295 cell line: a pluripotent model for human adrenocortical studies. Molecular and Cellular Endocrinology $10045-50$.

Rainey WE, Saner K \& Schimmer BP 2004 Adrenocortical cell lines. Molecular and Cellular Endocrinology 228 23-38.

Richard DE, Chretien L, Caron M \& Guillemette G 1997 Stimulation of the angiotensin II type I receptor on bovine adrenal glomerulosa cells activates a temperature-sensitive internalization-recycling pathway. Molecular and Cellular Endocrinology 129 209-218.

Riddle EL, Schwartzman RA, Bond M \& Insel PA 2005 Multi-tasking RGS proteins in the heart: the next therapeutic target? Circulation Research 96 401-411.

Rogers JH, Tamirisa P, Kovacs A, Weinheimer C, Courtois M, Blumer KJ, Kelly DP \& Muslin AJ 1999 RGS4 causes increased mortality and reduced cardiac hypertrophy in response to pressure overload. Journal of Clinical Investigation $104567-576$.

Romero DG, Plonczynski M, Vergara GR, Gomez-Sanchez EP \& GomezSanchez CE 2004 Angiotensin II early regulated genes in H295R human adrenocortical cells. Physiological Genomics 19 106-116.

Romero DG, Plonczynski MW, Gomez-Sanchez EP, Yanes LL \& GomezSanchez CE 2006 RGS2 is regulated by angiotensin II and functions as a negative feedback of aldosterone production in H295R human adrenocortical cells. Endocrinology 147 3889-3897.

Ross EM \& Wilkie TM 2000 GTPase-activating proteins for heterotrimeric $\mathrm{G}$ proteins: regulators of $\mathrm{G}$ protein signaling (RGS) and RGS-like proteins. Annual Review of Biochemistry 69 795-827.

Rossi GP, Sacchetto A, Pavan E, Palatini P, Graniero GR, Canali C \& Pessina AC 1997 Remodeling of the left ventricle in primary aldosteronism due to Conn's adenoma. Circulation 95 1471-1478. 
Rossi GP, Bernini G, Desideri G, Fabris B, Ferri C, Giacchetti G, Letizia C, Maccario M, Mannelli M, Matterello MJ et al. 2006 Renal damage in primary aldosteronism: results of the PAPY Study. Hypertension 48 232-238.

Roy AA, Lemberg KE \& Chidiac P 2003 Recruitment of RGS2 and RGS4 to the plasma membrane by $\mathrm{G}$ proteins and receptors reflects functional interactions. Molecular Pharmacology 64 587-593.

Rozen S \& Skaletsky H 2000 Primer3 on the WWW for general users and for biologist programmers. Methods in Molecular Biology 132 365-386.

Sato M, Blumer JB, Simon V \& Lanier SM 2006 Accessory proteins for G proteins: partners in signaling. Annual Review of Pharmacology and Toxicology 46 151-187.

Spat A \& Hunyady L 2004 Control of aldosterone secretion: a model for convergence in cellular signaling pathways. Physiological Reviews $\mathbf{8 4}$ 489-539.

Tamirisa P, Blumer KJ \& Muslin AJ 1999 RGS4 inhibits G-protein signaling in cardiomyocytes. Circulation 99 441-447.

Tanabe A, Naruse M, Naruse K, Hase M, Yoshimoto T, Tanaka M, Seki T \& Demura H 1997 Left ventricular hypertrophy is more prominent in patients with primary aldosteronism than in patients with other types of secondary hypertension. Hypertension Research 20 85-90.

Taymans JM, Kia HK, Claes R, Cruz C, Leysen J \& Langlois X 2004 Dopamine receptor-mediated regulation of RGS2 and RGS4 mRNA differentially depends on ascending dopamine projections and time. European Journal of Neuroscience 19 2249-2260.

Vasan RS, Evans JC, Larson MG, Wilson PW, Meigs JB, Rifai N, Benjamin EJ \& Levy D 2004 Serum aldosterone and the incidence of hypertension in nonhypertensive persons. New England Journal of Medicine 351 33-41.
De Vries L \& Gist Farquhar M 1999 RGS proteins: more than just GAPs for heterotrimeric G proteins. Trends in Cell Biology 9 138-144.

De Vries L, Zheng B, Fischer T, Elenko E \& Farquhar MG 2000 The regulator of $\mathrm{G}$ protein signaling family. Annual Review of Pharmacology and Toxicology 40 235-271.

Watson N, Linder ME, Druey KM, Kehrl JH \& Blumer KJ 1996 R GS family members: GTPase-activating proteins for heterotrimeric G-protein alphasubunits. Nature 383 172-175.

Wotus C, Levay-Young BK, Rogers L, Gomez-Sanchez CE \& Engeland WC 1998 Development of adrenal zonation in fetal rats defined by expression of aldosterone synthase and $11 \beta$-hydroxylase. Endocrinology 139 4397-4403.

Zhang S, Watson N, Zahner J, Rottman JN, Blumer KJ \& Muslin AJ 1998 RGS3 and RGS4 are GTPase activating proteins in the heart. Journal of Molecular and Cellular Cardiology 30 269-276.

Zhou MY, Gomez-Sanchez EP, Cox DL, Cosby D \& Gomez-Sanchez CE 1995 Cloning, expression and tissue distribution of the rat $\mathrm{NAD}+$-dependent $11 \beta$-hydroxysteroid dehydrogenase. Endocrinology 136 3729-3734.

Received in final form 7 May 2007

Accepted 9 May 2007

Made available online as an Accepted Preprint 15 May 2007 